\title{
Duodenal Injuries During Laparoscopic Cholecystectomy: An Unusual But Serious Complication of a Routine Surgical Procedure
}

\author{
Stamatios Angelopoulos, Orestis loannidis, Ioannis Mantzoros, Manousos-Georgios Pramateftakis, \\ Efstathios Kotidis, Loukiani Kitsikosta, Despoina Kyriakidou, Konstantinos Tsalis
}

$4^{\text {th }}$ Department of Surgery, Medical Faculty of Aristotle University of Thessaloniki, Greece

Corresponding author:

Orestis loannidis, MD, MSC

PhD Surgeon, Scientific Fellow

Fourth Surgical Department

Medical School

Aristotle University of Thessaloniki

Thessaloniki, Greece

E-mail: telonakos@hotmail.com

Abbreviations:

ERCP - endoscopic retrograde

cholangiopancreatography

CT - computed tomography

\section{Rezumat}

Rănirea duodenului în timpul colecistectomiei laparoscopice: o complicatie neobișnuită, dar gravă, în timpul unei intervenții chirurgicale de rutină

Rănirea duodenului este o complicație neobişnuită în timpul colecistectomiei laparoscopice, cauzată în principal de rănirea cu instrumentele laparoscopice, rănirea mecanică sau termică. Managementul este de obicei chirurgical, cu rezultate satisfăcătoare, atâta timp cât complicația este identificată în fază incipientă. Studiul de față prezintă două cazuri de perforatiii duodenale în timpul colecistectomiei laparoscopice. Într-unul din cazuri s-a procedat la închiderea primară a defectului, iar în celălalt s-a procedat conservator prin drenaj abdominal şi deprivare alimentară. Ambele tehnici au avut succes în managemenul complicației.

Cuvinte cheie: rănirea duodenului, colecistectomie laparoscopică

\section{Abstract}

Duodenal injury is an unusual complication of laparoscopic cholecystectomy, mostly caused by direct injury of the duodenum by laparoscopic instruments, either mechanical or thermal. The management is usually surgical, with satisfactory results, as long as the complication is detected early. We report two cases of duodenal perforations during laparoscopic cholecystectomy. One was treated with primary closure of the defect, while the other was managed conservatively with abdominal drainage and food deprivation. Both techniques proved successful in the management of that complication.

Key words: duodenal injury, laparoscopic cholecystectomy 


\section{Introduction}

Duodenal injury is an unusual and rather rarely reported complication of laparoscopic cholecystectomy. Duodenal perforations are usually caused by direct bowel injuries with the electrocautery device or by improper use of the laparoscopic instruments. A surgeon should be alarmed of the possibility of a duodenal injury when a patient develops intense abdominal pain, pyrexia and / or abdominal collection in the early postoperative days. Relaparoscopy is usually necessary in order to recognize the injury and early recognition often allows primary repair with satisfactory results.In this study we present two cases of patients with duodenal perforations after laparoscopic cholecystectomy. Each case was managed with different surgical techniques with success.

\section{Case reports}

\section{Case 1}

A 71 year old female patient was admitted to our clinic with acute abdominal pain, nausea and vomiting. Clinical and radiological examinations revealed cholelithiasis with signs of acute cholecystitis, therefore we proceeded to a laparoscopic cholecystectomy. Apart from minor difficulties during the dissection at the triangle of Calot due to the slightly abnormal course of the common bile duct, no other problems were noted intraoperatively. At the end of the procedure, an abdominal drain was inserted subhepatically. The immediate postoperative course was uneventful, with the patient complaining of mild epigastric discomfort only.

On the first postoperative day, the patient complained of increased epigastric pain and she developed mild leucocytosis $\left(15.07 \times 10^{9} / \mathrm{L}\right)$ with pyrexia. The abdominal drain started draining small amounts of bile. An endoscopic retrograde cholangiopancreatography (ERCP) was performed to assess the biliary anatomy for a possible leak. The endoscopist observed no site of biliary injury, and performed a papillary sphincterotomy. The patient's symptoms did not settle after the endoscopy, therefore a contrast-enhanced abdominal computed tomography (CT) was performed. The latter revealed the presence of gastrograffin intraperitoneally, indicating a possible bowel injury of the upper gastrointestinal tract. We proceeded to an exploratory laparotomy.

The laparotomy revealed a perforation of the anterior duodenal wall, between the second and the third part of the duodenum. Given the fact that the dissection at Calot's triangle was troublesome, we believed the perforation to be iatrogenic (thermal injury) during the dissection at the triangle and at the gallbladder fossa. The perforation was primarily sutured with absorbable sutures (3/0 Vicryl). Additionally, an omental patch was used to cover the injury site. The abdomen was washed thoroughly and a larger abdominal drain was inserted subhepatically before closure. In the next few days, the patient's symptoms, including fever and leucocytosis, settled. We removed the drain on the 10th postoperative day and she was discharged home one day later, free of symptoms.

\section{Case 2}

A 67 year old male patient was referred to our clinic with a known duodenal perforation 5 days after a laparoscopic cholecystectomy. At the time of presentation he had acute abdominal pain, fever and leucocytosis. We proceeded to a laparoscopic washout of the abdominal cavity and the insertion of two drains, one subhepatically and one subdiaphragmatically. On the 3rd postoperative day, and while the patient was still pyrexic with leucocytosis, we performed a contrast-enhanced abdominal CT scan. The latter revealed the presence of gastrograffin subhepatically, confirming the presence of a duodenal perforation. The patient was treated conservatively with antibiotics and food deprivation, and his clinical signs gradually improved. On the 20 th postoperative day radiological signs revealed 
no signs of gastrograffin leakage in the peritoneal cavity. We removed the drains and the patient was discharged home in good condition.

\section{Discussion}

Over the last century, laparoscopic cholecystectomy has gradually become the gold standard procedure for the treatment of cholelithiasis. Currently, throughout the world, more than $80 \%$ of cholecystectomies are performed using the laparoscopic technique (1). Numerous studies deal with complications associated with this surgical procedure. The main categories are complications related to the insertion of the Veress needle, complications related to the insertion of the trocars, bile duct injuries, intraoperative or postoperative haemorrhage and other complications such as thermic injuries, mechanical duodenal and diaphragmatic injuries and herniation at the trocar sites $(2,3)$. Iatrogenic duodenal injuries are rare complications, ranging between $0.2-3 \%$ (4). They appear to be of two types: penetrating bowel injury from either the Verress needle, a sharp-edged instrument like the suction/irrigation device or a trocar, and thermal injury from either direct contact with the electrocautery device or energy conduction burn $(4,5)$.

The suspicion of a duodenal injury should be raised whenever a patient develops diffuse abdominal pain, fever, leucocytosis, peritonitis or bile leakage following laparoscopic cholecystectomy (6). Mechanical injuries produce symptoms early after the operation, whereas in case of burns, the symptomatology may arise 2-3 weeks postoperatively. A high index of suspicion is indicated when the only symptom is pain at the right shoulder, which is common after laparoscopy but might indicate an abscess developing subdiaphragmatically (4).

A non-invasive diagnosis can be reached using ERCP, contrast-enhanced CT or contrast-enhanced upper GI series (gastrograffm-meal) (7,8). Upper-GI endoscopy is relatively contraindicated in the suspicion of a perforation, but it can sometimes become necessary. Usual radiological signs include right upper quadrant collections or free intraperitoneal fluid. Contrast upper-GI series often have a low sensitivity for small perforations, and false negative results have been reported in the literature (4). If a drain was inserted intraoperatively, it usually drains bile. Bile drainage raises the suspicion of a bile duct injury, but it could also indicate a duodenal injury.

Differential diagnosis includes various biliary lesions or traumas and general causes of peritonitis. Posterior duodenal perforations often produce no typical radiological signs, due to the fact that they get walled off and show no intraperitoneal fluid. Nevertheless, it is the symptomatology that finally leads the surgeon to the suspicion of a duodenal injury.

The definite diagnosis is usually set during a diagnostic laparoscopy $(9,10)$. If necessary, one can convert to a laparotomy. Intraperitoneal bile in the absence of leakage from the gallbladder fossa or an injury to the biliary tree usually indicates a duodenal injury. Another occasional finding is a posterior displacement of the duodenum due to a developing mass (11). After the duodenal injury is identified, one has various surgical options of treatment, and the method of choice depends on the extent of the injury, the time of identification and the clinical condition of the patient. The treatment options include a) simple drainage and insertion of drains, with closure of the perforation via secondary intention b) drainage and primary suturing of the defect, with or without an omental patch, or c) more complex surgical procedures like duodenostomy, gastrojejunostomy or choledochoduodenal anastomosis (12).

\section{Conclusion}

Duodenal perforation during laparoscopic cholecystectomy is a rare but serious complication. During dissection at the triangle of Calot, the duodenum is at risk of direct mechanical injury, contact burn or energy conduction burn. When postoperative clinical 
signs suggest the possibility of such a perforation, attempts should be made to recognize it early in order to proceed to surgical treatment. Early reoperation leads to satisfactory results.

\section{Conflict of Interest}

The authors declare no conflicts of interests.

\section{References}

1. Aslar AK, Ertan T, Oguz H, Gocmen E, Koc M. Impact of laparoscopy on frequency for treatment of gallstones. Surg Laparosc Endosc Percutan Tech. 2003;13:315-317.

2. Farkas E, Mrksic MB, Komlos A, Sarac M. Complications in laparoscopic cholecystectomy. Med Pregl 1999; 52: 253-257.

3. Marakis GN, Pavlidis TE, Balias K, Aimoniotou E, Psarras K, Karvounaris D, Rafailidis S, Demertzidis H, Sakantamis AK. Major complications during laparoscopic cholecystectomy. Int Surg 2007;92:142-146.
4. Croce E, Golia M, Russo R, Azzola M, Olmi S, De Murtas G. Duodenal perforations after laparoscopic cholecystectomy. Surg Endosc. 1999;13:523- 525.

5. Berry SM, Ose KJ, Bell RH, Fink AS. Thermal injury of the posterior duodenum during laparoscopic cholecystectomy. Surg Endosc. 1994;8:197- 200.

6. Debnath D. Bowel injury as a complication of laparoscopy. Br J Surg. 2004;91:1253-1258.

7. Jayaraman MV, Mayo-Smith WW, Movson JS, Dupuy DE, Wallach MT. CT of the duodenum: an overlooked segment gets its due. Radiographics. 2001;21:147-160.

8. Linsenmaier U, Wirth S, Reiser M, Komer M. Diagnosis and classification of pancreatic and duodenal injuries in emergency radiology. Radiographics. 2008;28:1591-1602.

9. Cone JB, Eidt JF. Delayed diagnosis of duodenal rupture. Am J Surg 1994;168:676-678.

10. Testini M, Piccinni G, Lissidini G, Di Venere B, Gurrado A, Poli E, et al. Management of descending duodenal injuries secondary to laparoscopic cholecystectomy. Dig Surg. 2008;25:12-15.

11. Peters JH, Gibbons GD, Innes JT, Nichols KE, Front ME, Roby SR, et al. Complications of laparoscopic cholecystectomy. Surgery. 1991;110:769-778.

12. Knudson K, Raeburn CD, McIntyre RC Jr, Shaw RJ, Chen YK, Brown WR, et al. Management of duodenal and pancreaticobiliary perforations associated with periampullary endoscopic procedures. Am J Surg. 2008;196:975-981. 